\title{
Stability Parameters for Comparing Bread Wheat Genotypes under Combined Heat and Drought Stress
}

N.E. M. Mohamed and A. A. Said

Agronomy Department, Faculty of Agriculture, Sohag

University, Sohag , Egypt

\begin{abstract}
A COMPARISON of ten local and twelve introduced wheat accessions was performed on twelve different induced environments ( 2 years $\times 2$ sowing dates $\times 3$ water stresses) to analyze genotype $\times$ environment interactions $(\mathrm{G} \times \mathrm{E})$ and estimate stability indices of yield and its components. Mainly the total variations of studied traits were due to the main effects of environmental factors and their interaction, whereas the significant environmental variations were ranged from $10.62 \%$ (harvest index) to $43.95 \%$ (spike kernels weight). The genotypes differed significantly for all studied traits, moreover these differences ranged from $6.82 \%$ to $50.42 \%$ of total variation in 1000-kernel weight and no. of kernels/spike, respectively. $\mathrm{G} \times \mathrm{E}$ interactions were highly significant and their contributions to the total SS accounted for 40.17, 30.78, 18.17, 22.02, 25.46, 18.61 and $88.46 \%$ for heading date, no. of spikes $/ \mathrm{m}^{2}$, no. of kernels/spike, spike kernel weight, 1000 -kernel weight, grain yield $/ \mathrm{m}^{2}$ and harvest index, respectively. Three genotypes (NGB10893, Sids1 and Giza168) were high yielding and stable for most of the studied traits. Thus, these three genotypes could be promoted to the next extensive breeding programs.
\end{abstract}

Keywords: Performance, Genotype $\times$ environment interaction, Stability parameters, Wheat.

Wheat (Triticum aestivum L.) is a very important cereal crop in Egypt as a source of human food. Growth rate of a human population in Egypt is still relatively high, thus the demand of wheat is being progressively increased. Overcoming the gap between cereal production and consumption depends mainly on horizontal extension of cultivated area of cereals and raising the yield per unit area is encountered by unfavorable conditions such as drought, heat and high salinity of soil. The first step is to identify, the superior tolerant genotypes to be used in the breeding program. However, stable wheat cultivars that are tolerant to different environmental stresses are the ultimate goal of the national wheat research program.

Stable genotypes have the same reactions across the environments. Most favorable stability occurs with high yield or performance (Björnsson, 2002). Increasing genetic gains in yield is possible in part from narrowing the adaptation of cultivars, thus maximizing yield in particular areas by exploiting genotype $\times$ environment interaction $(\mathrm{G} \times \mathrm{E}) . \mathrm{G} \times \mathrm{E}$ is of major importance, 
because it provides information about the effect of different environments on cultivar performance and has a key role for assessment of performance stability of the breeding materials (Moldovan et al., 2000 and Bose et al., 2014).

The regression coefficient (bi) and the average departure from regression line $\left(\mathrm{S}^{2} \mathrm{~d}_{\mathrm{i}}\right)$ are two mathematical indices for the assessment of stability (Eberhart \& Russell, 1966). A genotype with high bi and $S^{2} d_{i}$ reacts readily to changes in the environment and possesses considerable variability, whereas cultivars with a bi < 1.0 and $\mathrm{S}^{2} \mathrm{~d}_{\mathrm{i}}$ near to 0.00 react weakly to changes in growing conditions and are considered to be stable in yield (Shindin \& Lokteva, 2000).

The ability of a crop cultivar to perform reasonably well in variable abiotic stresses is an important trait for both the stability of production under drought conditions (Nachit \& Ouassou, 1988). Climate and weather conditions greatly influence the performance of new wheat cultivars both for yield and quality (Wajid et al., 2004; Sharma et al., 2006 and Abdullah et al., 2007). Selection for yield stability over stress sites and years was able to improve the stress resistance (Ortiz-Ferrara et al., 1991). Regression analysis as well as grain yield per se could be useful for identifying high yielding thermo tolerance genotypes (Abd-Elghani et al., 1994). In addition, there is a strong evidence that breeding for drought resistance should include both yield and stability improvement (Clark \& Townley-Smith, 1984). High temperature is one of the most important abiotic environmental factors during grain filling and may influence both the quantity and quality of the yield (Rehman et al., 2007, Anwar et al., 2011 and Hamidou et al., 2013). All genotypes significantly produced higher grain yields under normal date of sowing compare with late date of sowing, (Sial et al., 2005).

The objectives of the present study are to: (1) Evaluate the magnitude of $\mathrm{G} \times \mathrm{E}$ interactions, (2) Assess the stability parameters of grain yield and its components, (3) Show the degree of linear relationships either between these stability parameters or between their average of the studied traits of the 22 local and introduced wheat accessions and (4) Identify most stable genotypes under abiotic stresses (heat and drought).

\section{Materials and Methods}

\section{Plant material and experimental design}

Twenty two wheat genotypes from diverse origin including 10 local and 12 introduced genotypes were used in this study (Table 1). The experiments were conducted at the experimental farm of Faculty of Agriculture, Sohag University, Egypt. Two experiments were performed in each season at two different sowing dates (D) 20 th November and 20 ${ }^{\text {th }}$ December, 2011/2012 and 2012/2013 and three water irrigation treatments. The irrigation treatments were; (1) $I_{I}$ as normal irrigation in which wheat plants were supplied by water irrigation over all

Egypt. J. Agron. 36, No. 2 (2014) 
growth stages (10 irrigation frequencies), (2) $\mathrm{I}_{\mathrm{II}}$ water irrigations were reduced by three irrigations from the beginning of anthesis stage till harvest stage (7 irrigation frequencies) and (3) $\mathrm{I}_{\text {III }}$ was 5 irrigation frequencies only started from booting stage till the milk-ripe stage.. Overall, twelve different environments were created by manipulating environmental factors which were two years $\times$ two dates $\times$ three water irrigation treatments. Both the trend of temperature as a climatic factor and the soil status (particle-size distribution, soil texture and chemical analysis) as an edaphically factor reflected the variation between the two winter growing seasons of 2011/2012 and 2012/2013 as shown Fig. 1 and Table 2.

TABLE 1. Pedigree and source of 22 wheat accessions used in the study .

\begin{tabular}{|c|c|c|c|}
\hline $\begin{array}{l}\text { Entry } \\
\text { No. }\end{array}$ & Genotype & Pedigree & Source \\
\hline 1 & NGB90533 & --- & $\begin{array}{c}\text { Nord gene } \\
\text { bank }\end{array}$ \\
\hline 2 & Giza 164 & Kvz/Buha"s"//Kai/Bb=Veery"s" & Egypt \\
\hline 3 & Gemmeiza 3 & & “ \\
\hline 4 & NGB10992 & --- & $\begin{array}{c}\text { Nord gene } \\
\text { bank }\end{array}$ \\
\hline 5 & NGB11185 & --- & “ \\
\hline 6 & NGB11418 & --- & “ \\
\hline 7 & NGB4769 & --- & “ \\
\hline 8 & NGB4823 & --- & “ \\
\hline 9 & NGB6404 & --- & “ \\
\hline 10 & NGB6406 & --- & “ \\
\hline 11 & NGB8188 & --- & “ \\
\hline 12 & NGB8218 & 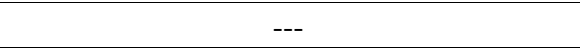 & “ \\
\hline 13 & NGB10893 & --- & “ \\
\hline 14 & Sids 1 & HD2172/Pavon"s"//1158.57/Maya74"s" & Egypt \\
\hline 15 & Sakha 69 & Inia/R1.4220//7C/Yr"s" & “ \\
\hline 16 & NGB10991 & --- & $\begin{array}{c}\text { Nord gene } \\
\text { bank }\end{array}$ \\
\hline 17 & Gemmiza 7 & --- & Egypt \\
\hline 18 & Sakha 8 & Indus 66 x Norteno"s"/PK3418-65-ISW-OS & “ \\
\hline 19 & Gemmeiza 1 & Maya 74/on//1160/147/3/Bb/Gall/ Chat"s" & “ \\
\hline 20 & Sahel 1 & NS 732/PIMA//Verry"s" & “ \\
\hline 21 & Giza 165 & Cno/Mfd//Man"s" & “ \\
\hline 22 & Giza 168 & Mill/Kauz//Kauz. & “ \\
\hline
\end{tabular}


TABLE 2. Soil status at the experimental farm of Faculty of Agriculture in Sohag University in both seasons (2011/12 and 2012/13) .

\begin{tabular}{|c|c|c|}
\hline Soil status & $2011 / 2012$ & $2012 / 2013$ \\
\hline \multicolumn{3}{|c|}{ 1- Mechanical properties of surface-soil $(0-30 \mathrm{~cm})$} \\
\hline Sand $(\%)$ & 50.35 & 49.51 \\
\hline Silt $(\%)$ & 18.72 & 19.40 \\
\hline Clay $(\%)$ & 30.93 & 31.09 \\
\hline Soil texture & Sandy-clay & Sandy-clay \\
\hline Organic mater $(\%)$ & 2.81 & 2.46 \\
\hline Total N (\%) & 0.153 & 0.181 \\
\hline \multicolumn{3}{|c|}{ 2- Chemical properties of surface-soil $(0-30 \mathrm{~cm})$} \\
\hline N PPM & 30 & 70 \\
\hline $\mathrm{P}_{2} \mathrm{O}_{5}$ & 17 & 47 \\
\hline $\mathrm{K}_{2} \mathrm{O}$ & 778 & 746 \\
\hline $\mathrm{Fe}$ & 2.88 & 6.36 \\
\hline $\mathrm{Zn}$ & 2.18 & 3.34 \\
\hline Mn & 8.56 & 12.86 \\
\hline $\mathrm{Cu}$ & 0.58 & 1.26 \\
\hline \multicolumn{3}{|c|}{ Soluble ions (meq/100g soil $(1: 5)$} \\
\hline $\mathrm{Ca}^{++}$ & 0.4 & 0.6 \\
\hline $\mathrm{Mg}^{++}$ & 1.6 & 3.4 \\
\hline $\mathrm{Na}^{++}$ & 1.73 & 2.6 \\
\hline $\mathrm{K}^{+}$ & 0.95 & 0.37 \\
\hline $\mathrm{HCO}_{3}^{-}$ & 0.2 & 0.8 \\
\hline $\mathrm{CL}$ & 1.6 & 2.0 \\
\hline $\mathrm{SO}_{4}$ & 2.88 & 4.17 \\
\hline $\mathrm{CaCo}_{3} \%$ & 5.4 & 5.6 \\
\hline $\mathrm{EC}(\mathrm{ds} / \mathrm{m})(1: 5)$ & 0.5 & 0.7 \\
\hline $\mathrm{pH}(1: 2.5)$ & 7.8 & 7.4 \\
\hline
\end{tabular}

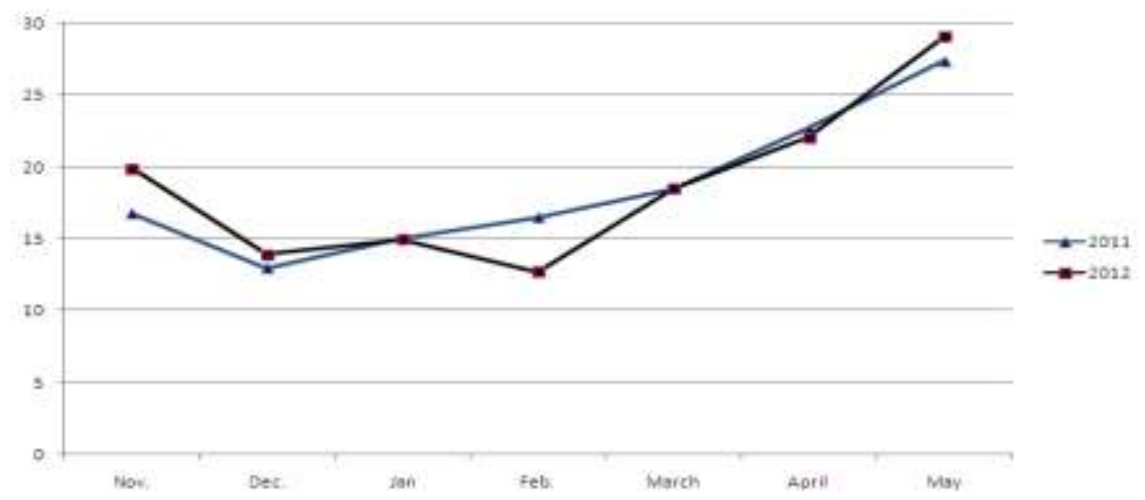

Fig. 1. The trend of temperature $\left({ }^{0} \mathrm{C}\right)$ during growing months of wheat plants in both seasons $(2011 / 12$ and 2012/13) . 
Split-plot design with three replications was used for every planting date, in which the water irrigation treatments were assigned to the main plots and the genotypes were randomly distributed to the sub plots. Data were recorded on days to $50 \%$ heading, number of spikes $/ \mathrm{m}^{2}$, number of kernels/spike, spike grain weight $(\mathrm{gm}), 1000$-kernel weight $(\mathrm{gm})$, grain yield $/ \mathrm{m}^{2}(\mathrm{gm})$ and Harvest index (gm) was calculated by using the following formula:

Harvest index $=($ Grain yield $) /($ Grain + straw yield $)$

\section{Statistical analyses}

The combined analysis, both in detail and collectively, was performed on the recorded data of grain yield and its components of the 22 genotypes over all the twelve environments according to Gomez \& Gomez (1994). The stability parameters C.V. \%, bi, $B_{i}, S^{2} d_{i}$ and $r^{2}$ were assessed to each of the 22 genotypes over all environments. Where C.V.\% was estimated according to Francis \& Kannenbert (1978), $b_{i}$ and $S^{2} d_{i}$ were estimated by using Eberhart \& Russell's model (1966) and $\beta_{\mathrm{i}}$ as described by Perkins \& Jinks (1968). Consequently, a stable genotype is a genotype has a regression coefficient of unity $\left(b_{i}=1.0\right)$ and a deviation from regression mean squares equals zero $\left(S^{2} d_{i}=0\right)$ and hence an ideal genotype would have both a high average performance over a wide range of environments together with stability parameters as defined by Eberhart \& Russell (1966). The coefficient of determination $\left(r^{2}\right)$ was proposed to use by Pinthus (1973), because it measures the proportion of a genotype's production variation that is attributable to the linear regression as an index of production stability over environments.

A correlation among stability indices $\left(\bar{X}\right.$, C.V. $\%, b_{i}, \beta_{i}, S^{2} d_{i}$, and $r^{2}$ ) was performed by using simple correlation (Fisher \& Yates, 1953). LSD was computed to compare the differences among means of genotypes while each regression coefficient was tested by $t$ test using the standard error of the corresponding $\mathrm{b}$ value. The degree of linear relationships (r's) was also calculated among the studied traits in this study to examine their mutual effects.

\section{Results and Discussion}

\section{Environment-Genotype variations and GxE interactions}

Combined analysis of variance of the studied traits (Table 3) showed that all the variations in the total sum of squares were attributed to the various environmental factors (Y,D and I) and their interactions which always were statistically significant or highly significant with the exception of $Y \times D$ interaction of no. of kernels/spike, 1000-kernel weight and harvest index.

The total variations in the studied traits were mostly due to the main effect of the environmental factors (Y, D, and I) which their variations ranged from $10.39 \%$ for harvest index to $41.82 \%$ for grain weight/spike. This range among the studied wheat features descended from the highest value of the effects of water stresses $(15.29 \%)$ to planting dates $(3.68 \%)$ to years $(0.44 \%)$. Environmental factors interactions also contributed to a small extent to the total 
variations and these contributions extended from $0.23 \%$ for harvest index to $4.14 \%$ for days to heading and most of these interaction variations were due to $\mathrm{D} \times \mathrm{I}$ interaction over all the studied traits with exception of 100-kernel weight which was much more sensitive to $\mathrm{Y} \times \mathrm{I}$ interaction (Table 3).

The previous findings reflected on the environmental variations which were highly significant and estimated by 31.63, 36.42, 27.98, 43.95, 15.28, 12.98 and $10.62 \%$ of the total variations for days to $50 \%$ heading, no. of spikes/ plant, no. of kernels/spike, spike kernel weight, 1000 kernel weight, grain yield plot" and harvest index, respectively (Table 4). These environmental variations were a direct result of : (1) The wide variations in climatic and edaphic factors between the two winter growing seasons (Table 1 and Fig. 1), (2) The effects of optimum and late sowing dates, and (3) The influence of water stress on yield and its components (EI-Morshidy et al., 1998 and 2000). So, these results emphasize that adopting the proper agricultural practices, especially sowing on the proper time with no water stress during the growing season, would visibly reduce a large amount of the environmental variations either by diminishing its main effect or by lessening its interactions or both.

The analyzed data also revealed that there were highly significant differences among genotypes for all the studied features across environments. Moreover, the contribution of the genotype variations to the total sum of squares was ranged from $6.82 \%$ (100-kernel weight) to $50.42 \%$ (no. of kernels/spike). Obviously, all degrees of $\mathrm{G} \times \mathrm{E}$ interactions were significant with exception of 100-kernel weight. In addition, the range of $\mathrm{G} \times \mathrm{E}$ contributions to the total SS were from $18.17 \%$ (no. of kernels/spike) to $88.46 \%$ (harvest index) over all the studied plant characters in used environments (Tables 3 and 4). The genetic diversity and the significant $\mathrm{G} \times \mathrm{E}$ interactions imply both sensitivity of genotypes and differential responses of these genotypes to various environments, suggesting the importance of stability parameters assessment of these genotypes under these conditions to identify the best stable suitable genotypes under this range of environments. Saini \& Gautam (1990) stated that the range of contributions of both environmental effects and genetic differences to the total SS was from 31.0 to $72.1 \%$ for environmental effects and from 8.3 to $34 \%$ for the genetic differences. Moreover, Nachit et al. (1992) showed that the mean squares of environments, genotypes and $\mathrm{G} \times \mathrm{E}$ interactions of the analysis of variance of wheat genotypes were highly significant and accounted for $89.3 \%, 0.5 \%$ and $10.2 \%$ of the treatment combinations SS, respectively. The results in this study are generally in harmony with previous studies (EI-Defrawy et al., 1994; Kheiralla \& Ismail, 1995; Ismail, 1995, EI-Morshidy et al., 1998 and 2000; Kheiralla et al., 2004 and Bose et. al., 2014).

Egypt. J. Agron. 36, No. 2 (2014) 


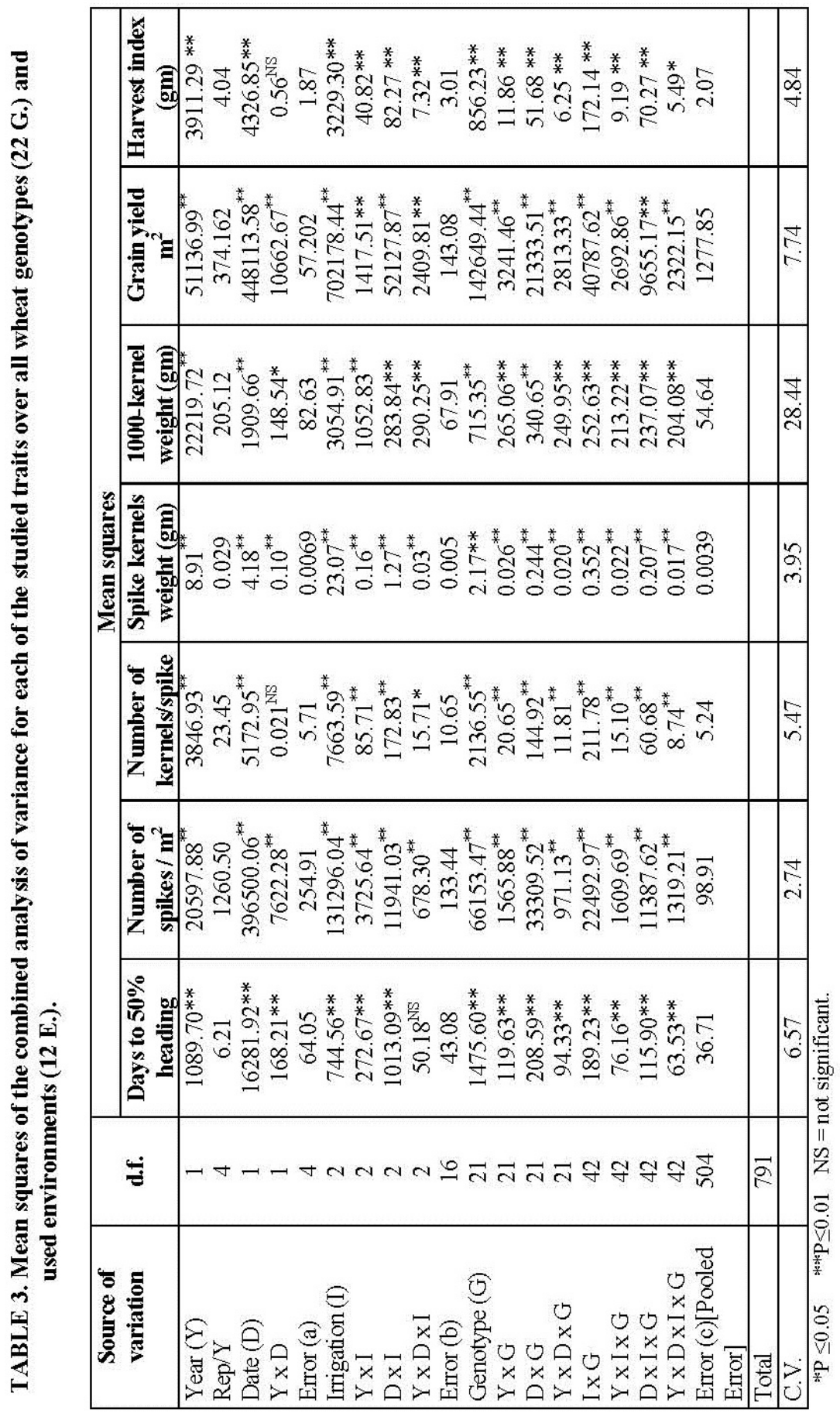

Egypt. J. Agron. 36, No. 2 (2014) 


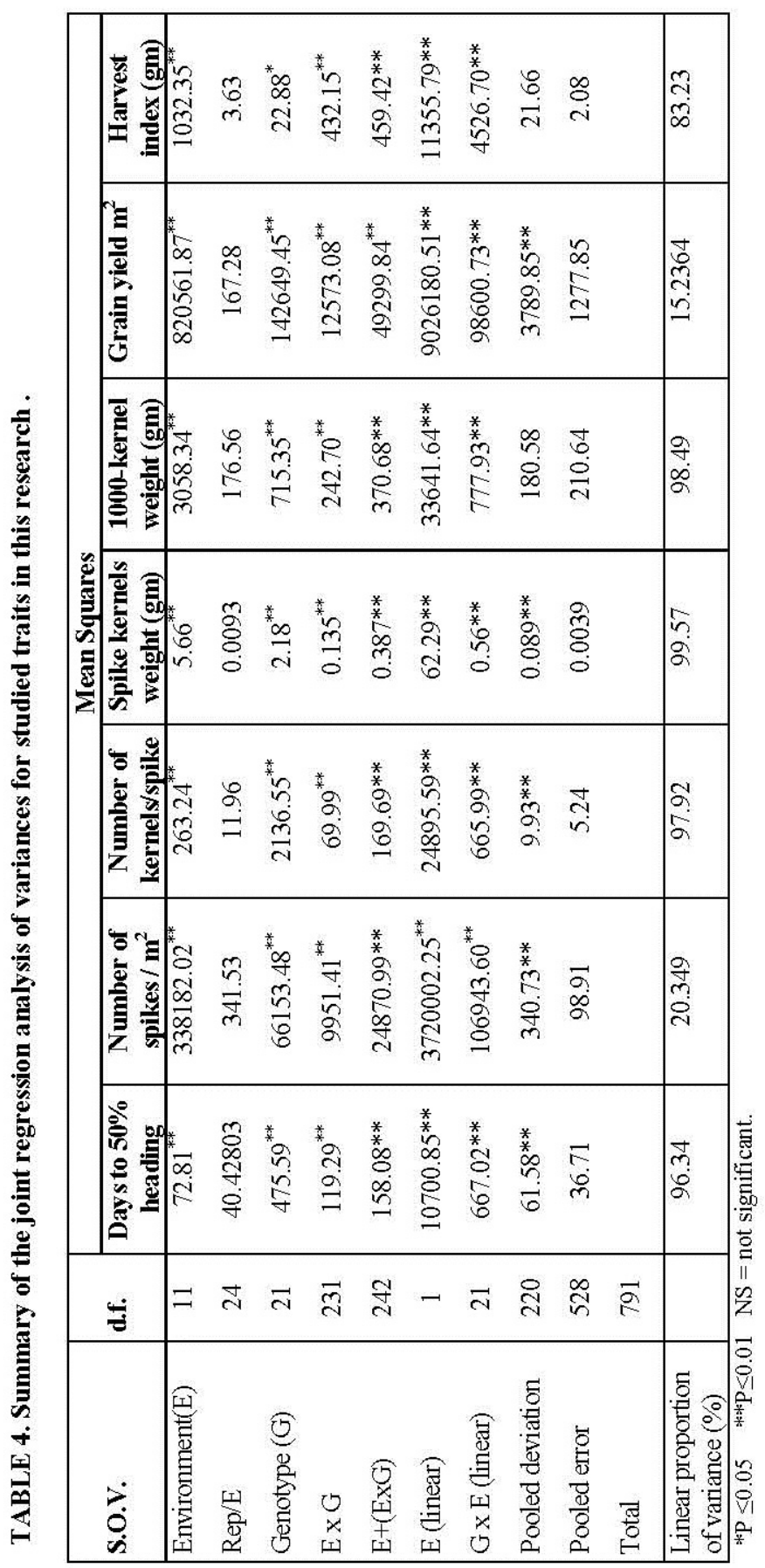

Egypt. J. Agron. 36, No. 2 (2014) 


\section{Joint regression analyses}

Analysis of variance of the studied traits over all environments and genotypes when stability parameters are estimated for each genotype across all environments are presented in Table 4 . All mean squares of $\mathrm{E}+\mathrm{G} \times \mathrm{E}$ were highly significant and the contributions of their SS to the total SS over all traits ranged from $40.74 \%$ (1000-kernel weight) to $98.53 \%$ (harvest index). In fact, (E+G×E) ss for each trait is only a makeup of the two parts; Ess and G×Ess of the same trait. Ess is completely represented by E (linear) ss which its mean square was highly significant for the studied traits, emphasizing again that there were much differences among environments and their influences would remarkably reflect on the studied traits. Also, the partition of G×Ess interaction of the studied traits into its two components; i.e., regression ss [G $\times \mathrm{E}$ (Iinear)ss] and deviations from regression ss [pooled deviations], demonstrated that: (1) GxE (linear) ss's for five out of the six studied traits were statistically significant, implying that it could be proceeding in assessment of stability parameters using Eberhart \& Russell's model (1966). (2) The contributions of $\mathrm{G} \times \mathrm{E}$ (linear) ss's to $\mathrm{G} \times \mathrm{E}$ interaction ss's over all the studied traits ranged from $29.14 \%$ (1000-kernel weight) to $96.74 \%$ (no. of spikes/plant), emphasizing the importance of the stable parameter $S^{2} d_{i}$ as defined by the previous studies. (3) The highly significance of deviation mean squares in this research pointed out to both considerable variations among genotypes in their stabilities and also visual variability of genotypes relative ranking from one environment to another. These data are coincident with Eberhart \& Russell (1966), Nachit et al. (1992), Kheiralla \& Ismail (1995), Ismail (1995), EI-Morshidy et al. (1998 and 2000), Kheiralla et al. (2004), Mustãţea1 et al. (2009) and Koumber et al. (2011).

\section{Estimated stability parameters}

It is important to report that plant breeders in executing selection programs would prefer to select genotypes with high average performance and most stable across various environments. Our data in Table 6 suggest that it is possible to select from wheat accessions in this study using a combination of both response and stability production indices. Langer et al. (1979) stated the same conclusion in oat varieties. Therefore, in the present study genotype will be selected if it has higher mean performance than the grand mean, higher $r^{2}$, low c. v. $\%$, bi $=1$ and smaller $S^{2}$ di. This is, in brief, because higher $r^{2}$ means that the linear model fits the data with the other parameters which will pronounce on well performed and the most stable suitable genotype.

\section{Days to $50 \%$ heading}

The studied genotypes appeared to have a wide range of variability in mean heading dates as shown in Table 5 and Fig. 2a. The range of heading dates among genotypes was about 23 days with an average of 91.79 days. Obviously, the C.V.'s\% among genotypes was low, therefore, the stability will be determined on the basis of $\mathrm{r}^{2}$, bi and $\mathrm{S}^{2} \mathrm{di}$ (Table 5). Sixteen genotypes were stable due to their bi's and $\mathrm{S}^{2}$ di's did not differ from a unit and the zero, 
respectively plus showing high $\mathrm{r}^{2}$. Six of the 22 studied genotypes $(2,5,6,13,20$ and 22) are considered as ideal in stability parameters although they were slightly late in heading. This significant deviation from regression for heading date was attributed by Joppa et al. (1971) to specific cultivar $\times$ location or other specific cultivar $\times$ environment interaction. These results are generally in line with those reported by EI-Defrawy et al. (1994), Kheiralla \& Ismail (1995), Ismail (1995) and EI-Morshidy et al. (1998 and 2000).

\section{Number of spikes/plant}

Out of the 22 studied genotypes, $8(2,6,11,13,14,15,16$ and 19) showed acceptable production statistics of both responses and stability for the number of spikes/plant (Table 5 and Fig. 2b). They demonstrated high or insignificant average comparing to the grand mean, low C.V.\% values, higher $r^{2}$, and insignificant bi and $S^{2}$ di. Similar results were reported by Salem et al. (1990), Ismail (1995), EI-Morshidy et al. (1998 and 2000) and Kheiralla et al. (2004).

\section{Number of kernels/spike}

The mean no. of kernels/spike ranged from 27.53 (genotype 14) to 56.57 (genotype 20) with an average of 42.10 (Table 5 and Fig. 2c). Six genotypes (3, $14,17,18,21$ and 22) have high average comparing to the grand mean with low C.V. values, high $\mathrm{r}^{2}$, and insignificant bi and $\mathrm{S}^{2}$ di.. Similar results were reported by Bansal \& Sinha (1991 b). The data also revealed that genotypes with higher bi gave higher number of kernels/spike, this is due to the positively significant association between $\bar{X}$ and bi $(\mathrm{r}=0.448 *)$. These findings are in agreement with those obtained by Salem et al. (1990), EI-Morshidy et al. (1998 and 2000) and Mustãţeal et al. (2009).

\section{Spike kernels weight (gm)}

Average spike kernels weight ranged from 1.19 (genotype 12) to $2.08 \mathrm{gm}$ (genotype 14) with an average of $1.59 \mathrm{gm}$ (Table 5 and Fig. 2d). Using the parameters bi, $\mathrm{S}^{2} \mathrm{di}, \mathrm{C} . \mathrm{V} . \%$ and $\mathrm{r}^{2}$ as selection criteria to the stability in this trait associated with high mean. Six stable genotypes $(2,6,8,14,18$ and 22) were selected when compared with the average over all genotypes. According to Eberhart \& Russell (1966), these genotypes may be considered superior. Again, the relationship between $\bar{x}$ and bi was highly positively significant $\left(\mathrm{r}=0.523^{* *}\right)$ (Table 6). Similar results were reported by EI-Morshidy et al. (1998 and 2000).

\section{0-kernels weight (gm)}

The studied accessions differed in their averages of 1000-kernels weight which ranged from 29.83 (genotype 3) to 45.62 gm (genotype 13) with an average of $37.76 \mathrm{gm}$ (Table 5, and Fig. 3e). Eighteen genotypes could be defined as the most stable suitable genotypes according to selection criteria. These genotypes were characterized by having low C.V. \%, high $\mathrm{r}^{2}$, insignificant bi and $\mathrm{S}^{2}$ di. Additionally, eight genotypes $(2,8,12,11,13,14,16$ and 22) were the most desired genotypes for 1000-kernels weight and showed high mean 
performance when compared with grand mean beside their stability. Noticeably, the relationship between $\bar{x}$ and bi, for this trait (Table 6) was positively significant $\left(0.446^{*}\right)$, indicating that the well performed genotypes (with higher bi) across varying environments would produce higher 1000-kernels weight. Similar results were obtained by Salem et al. (1990), Ismail (1995), EI-Morshidy et al. (1998 and 2000) and Mustãţea1 et al. (2009).

\section{Grain yield $/ \mathrm{m}^{2}(\mathrm{gm})$}

The studied genotypes appeared to have a wide range of variability in average grain yield as shown in Table 5 and Fig. 3f. Mean grain yield ranged from $362.31 \mathrm{gm} / \mathrm{m}^{2}$ (genotype 12) to $579.78 \mathrm{gm} / \mathrm{m}^{2}$. (genotype 2) with an average of $462.05 \mathrm{gm} / \mathrm{m}^{2}$. Concerning the estimated stability parameters (C.V. \%, $\mathrm{r}^{2}$, bi and $\mathrm{S}^{2} \mathrm{di}$ ) for this trait, most of the C.V.'s \% for the studied genotypes were close to the acceptable upper limit in the agriculture research $(<25 \%)$, this was due to the sensitivity of yield to different environments as well it is actually a net product of the physiological processes within a plant. Coefficient of determinations was also so high and ranged from 0.80 to 0.97 over all genotypes. In a simultaneous consideration to the stability parameters bi and $\mathrm{S}^{2} \mathrm{di}$, out of the 22 genotypes 15 were stable over all the studied environments; i.e. their bi and $\mathrm{S}^{2}$ di were insignificant. More than half of these stable genotypes (7) showed high yield; i.e. above the grand mean. According to ascending orders of yields to these genotypes, the stable genotypes were 8 (523.56 gm), 10 (494.69 gm), 11 (525.11 gm), 13 (521.06 gm), 14 (502.39 gm), 18 (477.97 gm) and $22(567.75 \mathrm{gm})$, (Table 5). It was clear to notice that genotypes no. 8, 10, 12, $13,15,18$ and 20 were stable and exhibited low average response to different environments $(\mathrm{bi}<1.0)$, they considered relatively better in stressed environments. The genotypes no. 1, 3, 11, 17, 19 and 21 performed consistently better in favorable environments ( $\mathrm{bi}>1)$. The most desired and stable genotypes can be considered when their regression coefficient equal one (bi=1) with lower values of $\mathrm{S}^{2} \mathrm{~d}_{\mathrm{i}}$ (Eberhart \& Russell, 1966), accordingly in this study both genotypes no. 14 and 22 were considered as desired and stable for grain yield when compared with grand mean. The large variation in mean grain yield, C.V. \%, bi and $S^{2} d_{i}$ indicated different responses of genotypes to environmental changes (Akçura et al., 2005). Our results are in line with those obtained by Bansal \& Sinha (1991b), Abd EI-Ghani et al. (1994), Kheiralla \& Ismail (1995), Ismail (1995), EI- Morshidy et al. (1998 and 2000), Mustãţea1 et al. (2009), Anwar et. al. (2011) and Koumber et. al. (2011).

\section{Harvest index}

Data in Table 5 and Fig. $3 g$ indicated that the mean of harvest index ranged from 23.13 (genotype 4) to 39.47 gm (genotype 22) with an average of $29.78 \mathrm{gm}$. The results showed that sixteen genotypes were matched with selection criteria to be defined as the most stable suitable genotypes. These genotypes showed low C.V. \%, high $\mathrm{r}^{2}$, and insignificant bi and $\mathrm{S}^{2} \mathrm{~d}_{\mathrm{i}}$. The most desired genotypes for harvest index were 3, 8, 10,14, 16, 18 and 22 due to their high mean performance when compared with grand mean and their stability. 


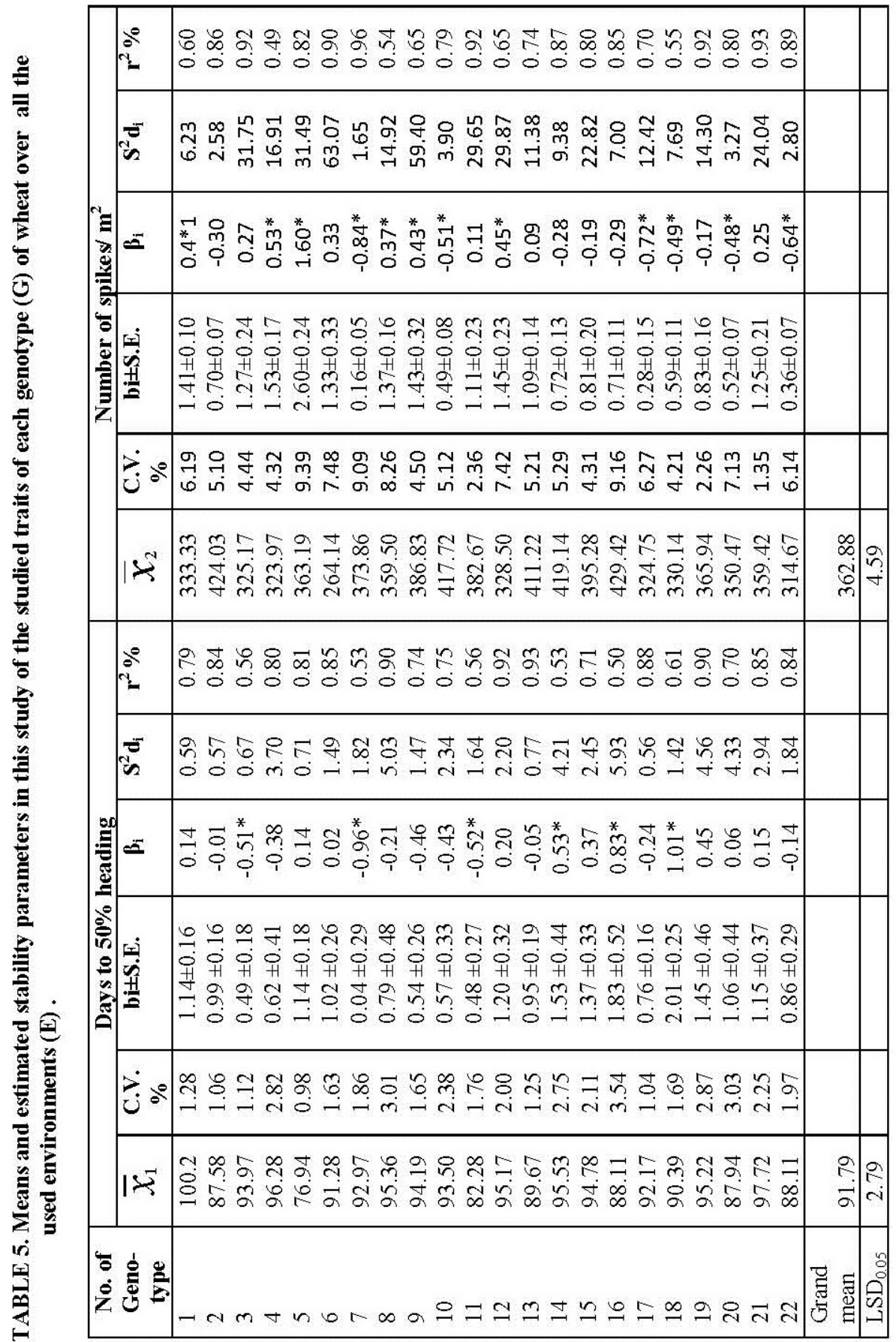

Egypt. J. Agron. 36, No. 2 (2014) 
STABILITY PARAMETERS FOR COMPARING BREAD ...

\begin{tabular}{|c|c|c|c|c|}
\hline \multirow{6}{*}{ 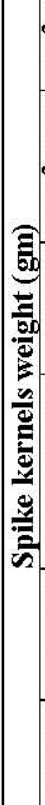 } & $y$ & 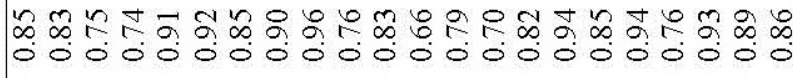 & & \\
\hline & 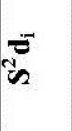 & 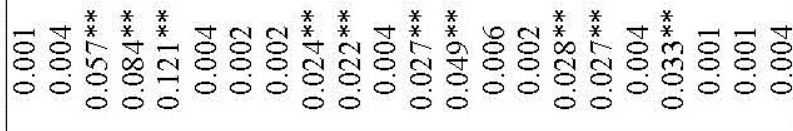 & & \\
\hline & $=$ & 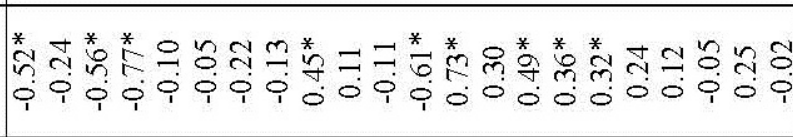 & & \\
\hline & 至 & 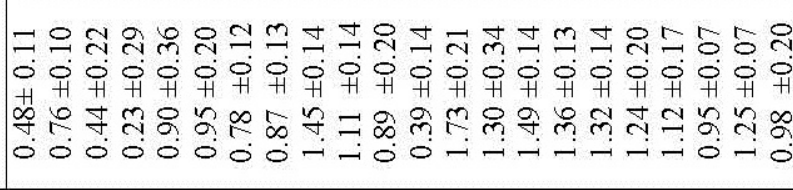 & & \\
\hline & 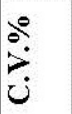 & 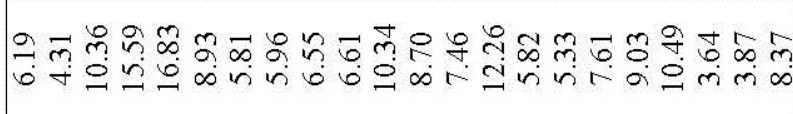 & & \\
\hline & 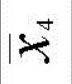 & 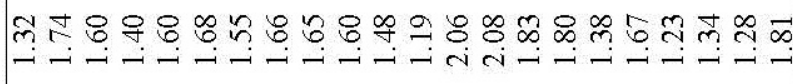 & $\stackrel{8}{-2}$ & 8 \\
\hline \multirow{6}{*}{ 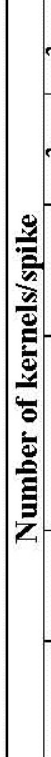 } & $\stackrel{8}{i}$ & 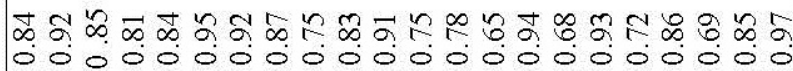 & & \\
\hline & 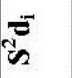 & 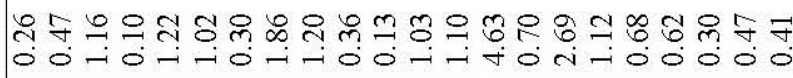 & & \\
\hline & & 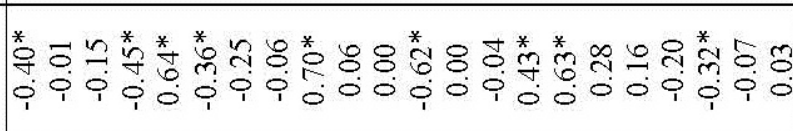 & & \\
\hline & 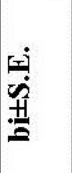 & 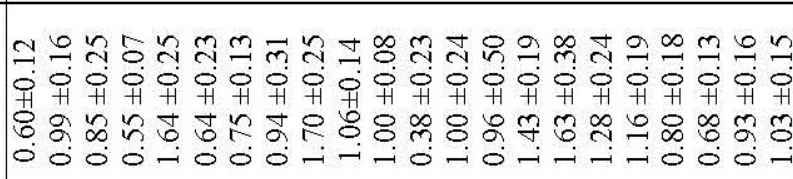 & & \\
\hline & $\dot{v}^{\circ}$ & 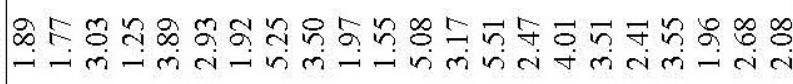 & & \\
\hline & im & 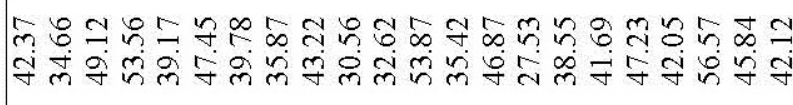 & $\stackrel{\circ}{\stackrel{0}{\sim}}$ & $\stackrel{\circ}{-}$ \\
\hline & $\stackrel{1}{\Xi}$ & 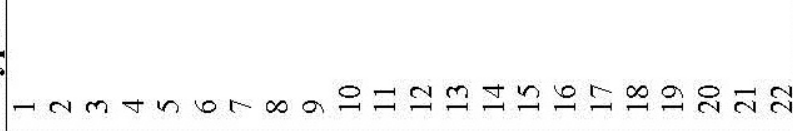 & 莺 & : \\
\hline
\end{tabular}

Egypt. J. Agron. 36, No. 2 (2014) 


\begin{tabular}{|c|c|c|c|}
\hline \multirow{6}{*}{ 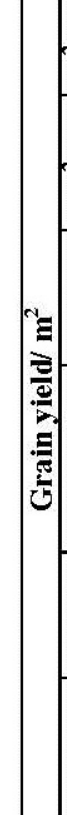 } & i & ڤ. & \\
\hline & $\bar{E}$ & 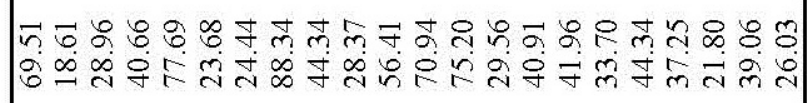 & \\
\hline & $=$ & 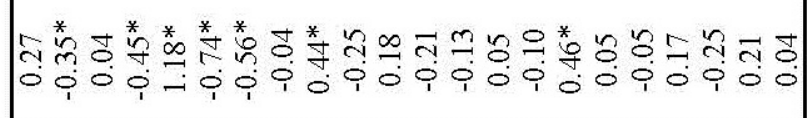 & \\
\hline & & 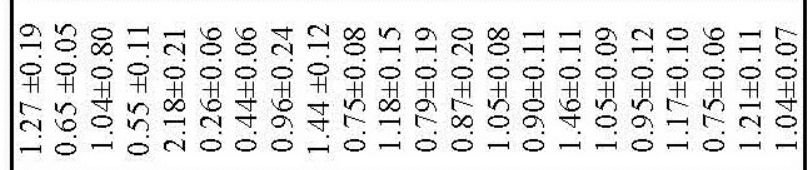 & \\
\hline & 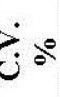 & 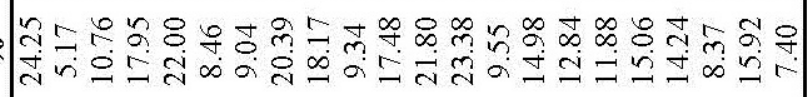 & \\
\hline & $1 x^{\circ}$ & 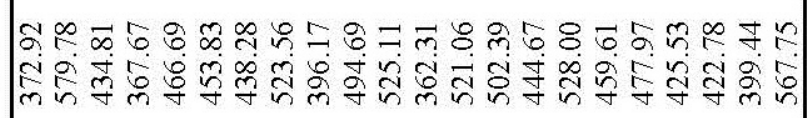 & 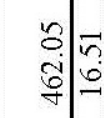 \\
\hline & 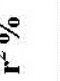 & 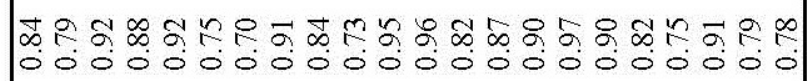 & \\
\hline & $\vec{E}$ & 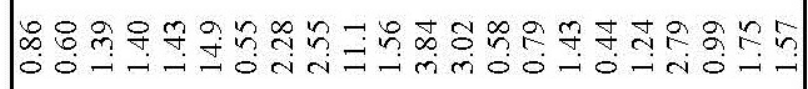 & \\
\hline 충 & $\Leftrightarrow$ & 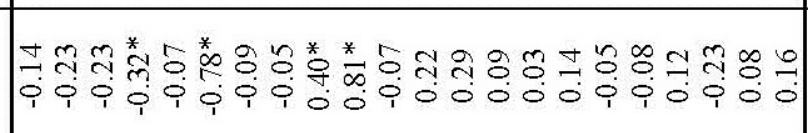 & \\
\hline : & 迹 & 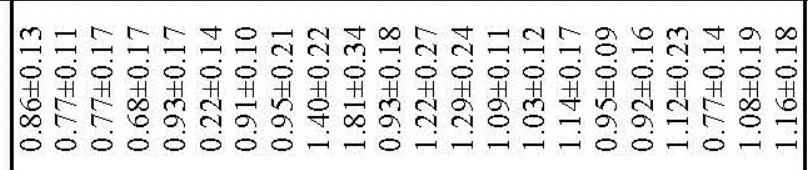 & \\
\hline & ن & 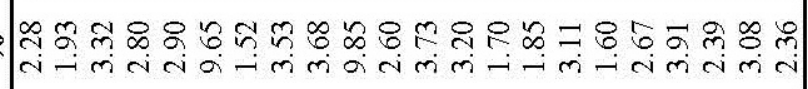 & \\
\hline & $1 \%$ & 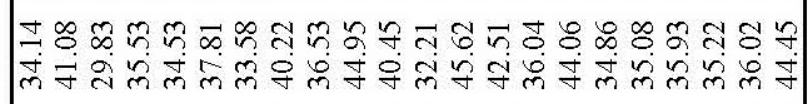 & $\stackrel{\circ}{i}=$ \\
\hline & & . & 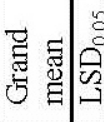 \\
\hline
\end{tabular}

Egypt. J. Agron. 36, No. 2 (2014) 


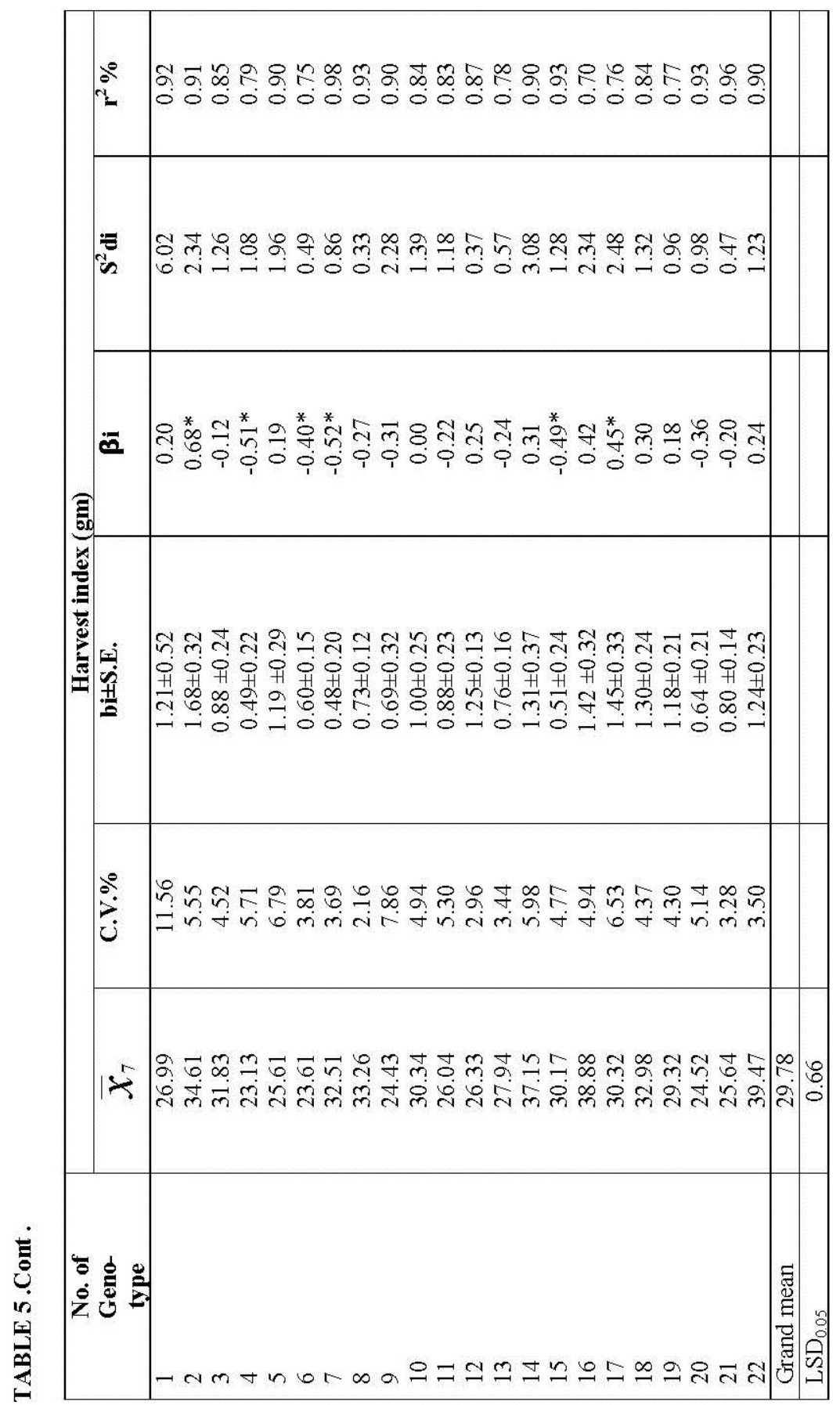

Egypt. J. Agron. 36, No. 2 (2014) 
(a) Days to $50 \%$ heading

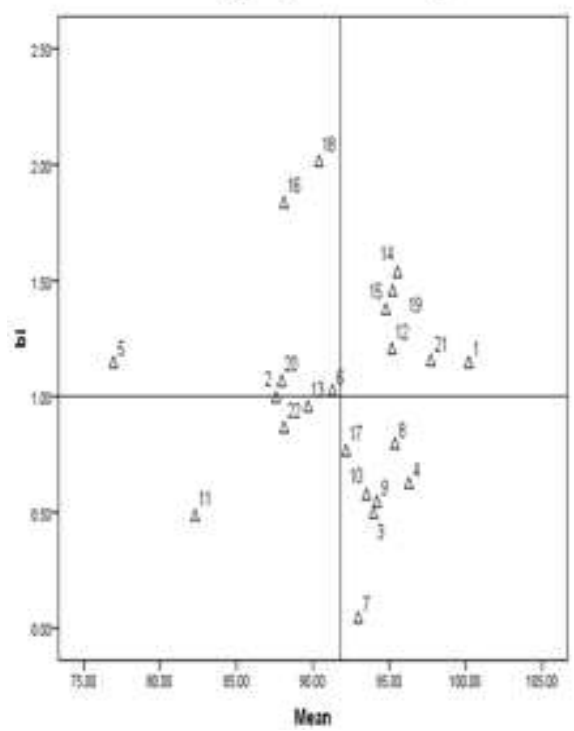

(c) Number of kernels/spike

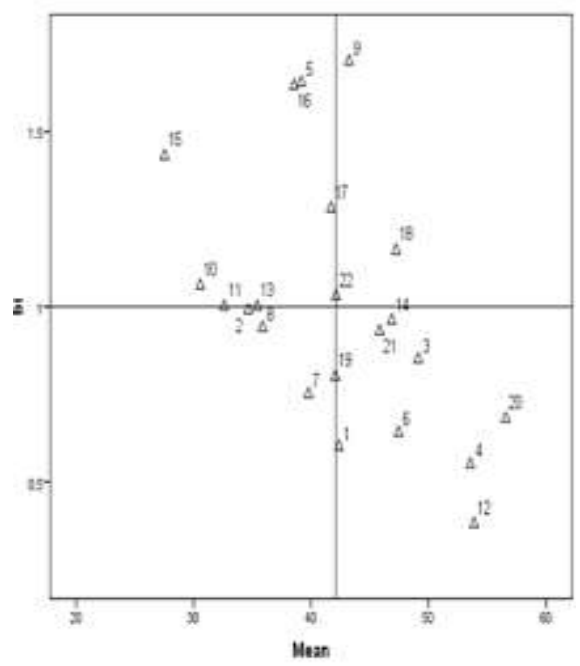

(b) Number of spikes $/ \mathrm{m}^{2}$

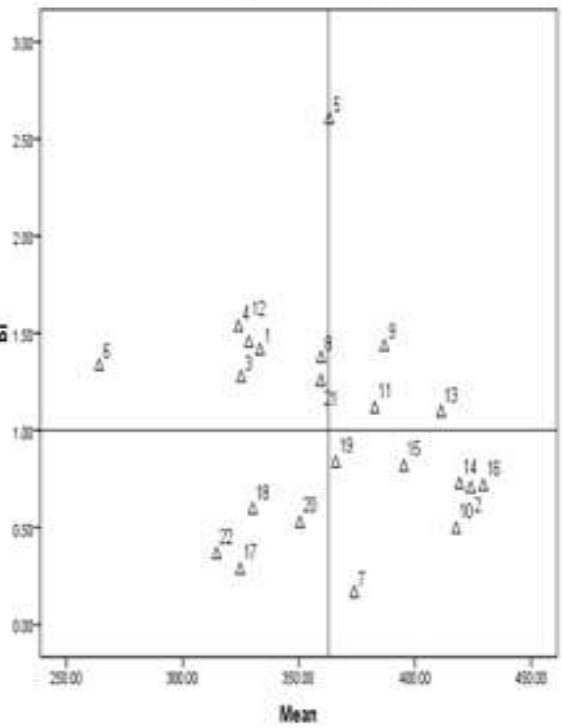

(d) Spike kernels weight (gm)

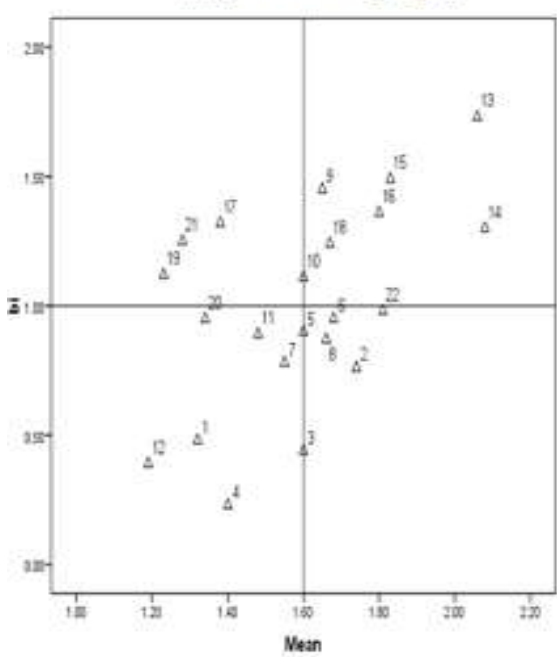

Fig. 2. Present graphically the relationships between the stability parameters (bi) and its mean performance of each genotype of the $22^{\text {th }}$ genotypes for (a) Days to $50 \%$ heading, (b) Number of spikes/plant, (c) Number of kernels/spike and (d) Spike kernels .

Egypt. J. Agron. 36, No. 2 (2014) 

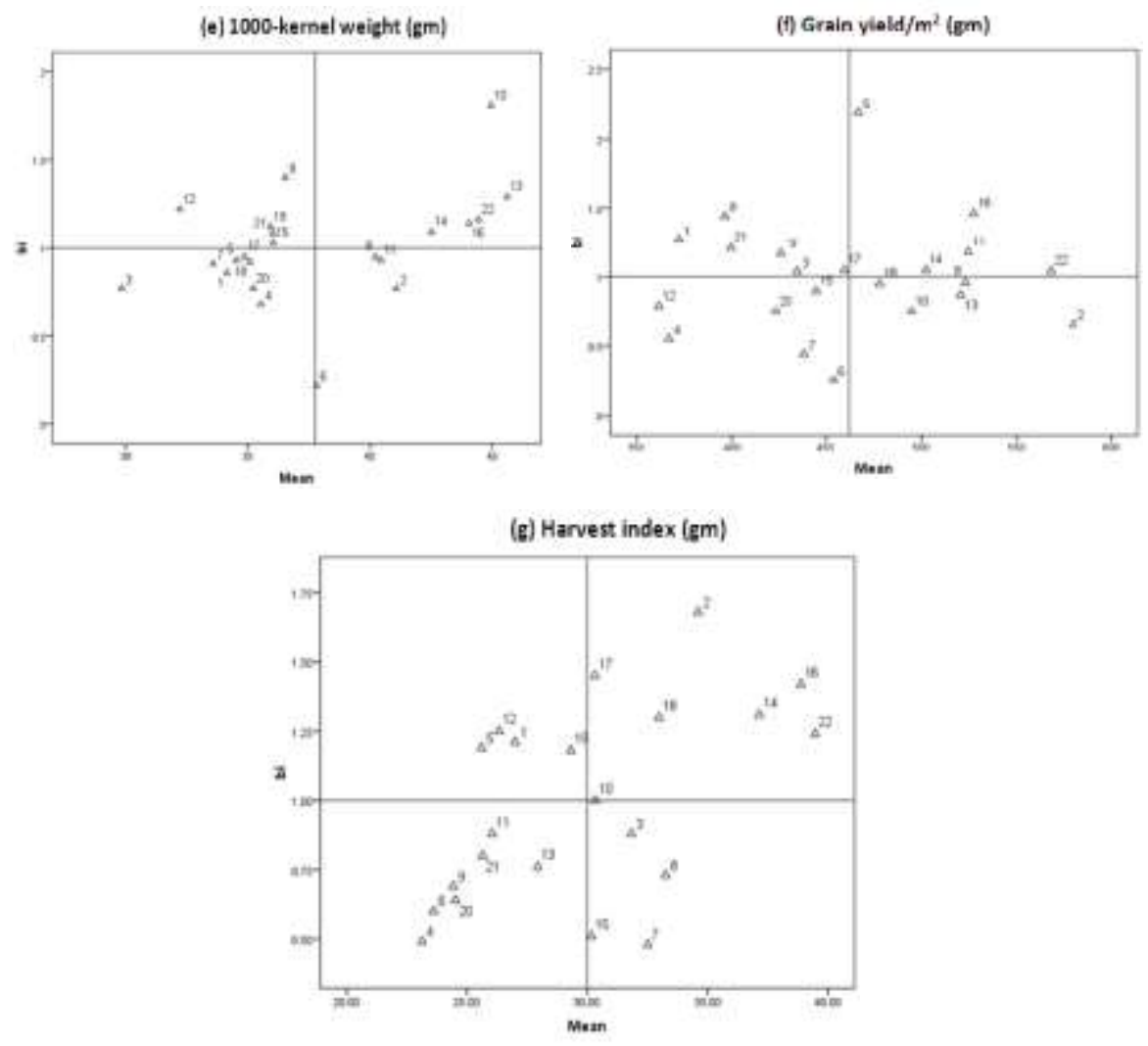

Fig. 3. Present graphically the relationships between the stability parameters (bi) and its mean performance of each genotype of the $22^{\text {th }}$ genotypes for (e) 1000 kernels weight, (f) Grain yield $/ \mathrm{m}^{2}$ and (g) Harvest index.

The data also indicated that genotypes with high bi, gave higher harvest index (Table 6), indicated by highly positive significant association between $\bar{x}$ and bi $\left(\mathrm{r}=0.556^{* *}\right)$. These results are in agreement with those obtained by Salem et al. (1990).

Further investigation to the data was also done using all possible combinations of pairwise simple correlations ( $r$ ) among the studied traits on the basis of the average of each genotype over all environments (Table 7). Understanding these correlations among traits is of paramount importance to increase the yield. Wherever these correlations serve as a guide for incorporating the economic characters and often a reduction in one yield component may be compensated by an increase in another (Bansal \& Sinha, 1991 b and EI- Defrawy et al., 1994). 


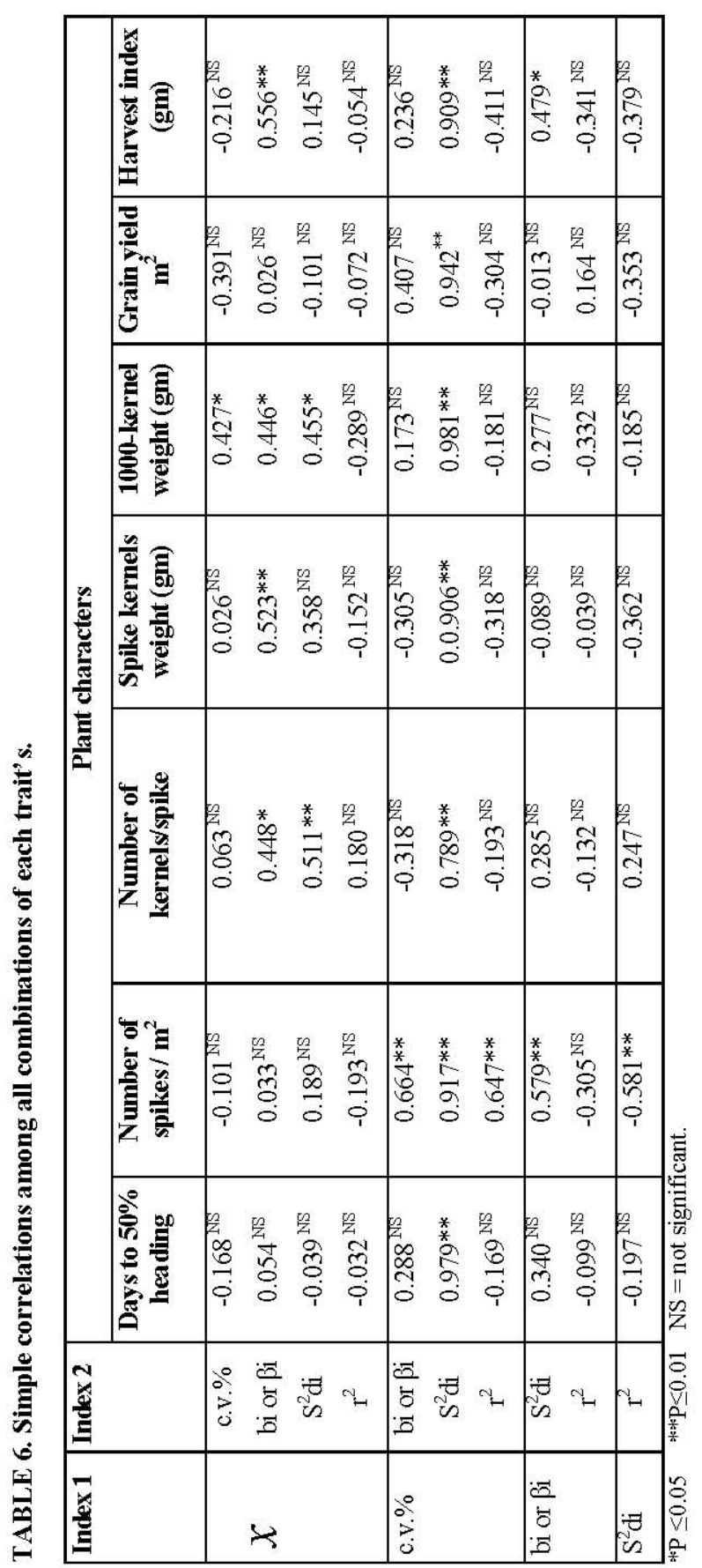

Egypt. J. Agron. 36, No. 2 (2014) 
STABILITY PARAMETERS FOR COMPARING BREAD ...

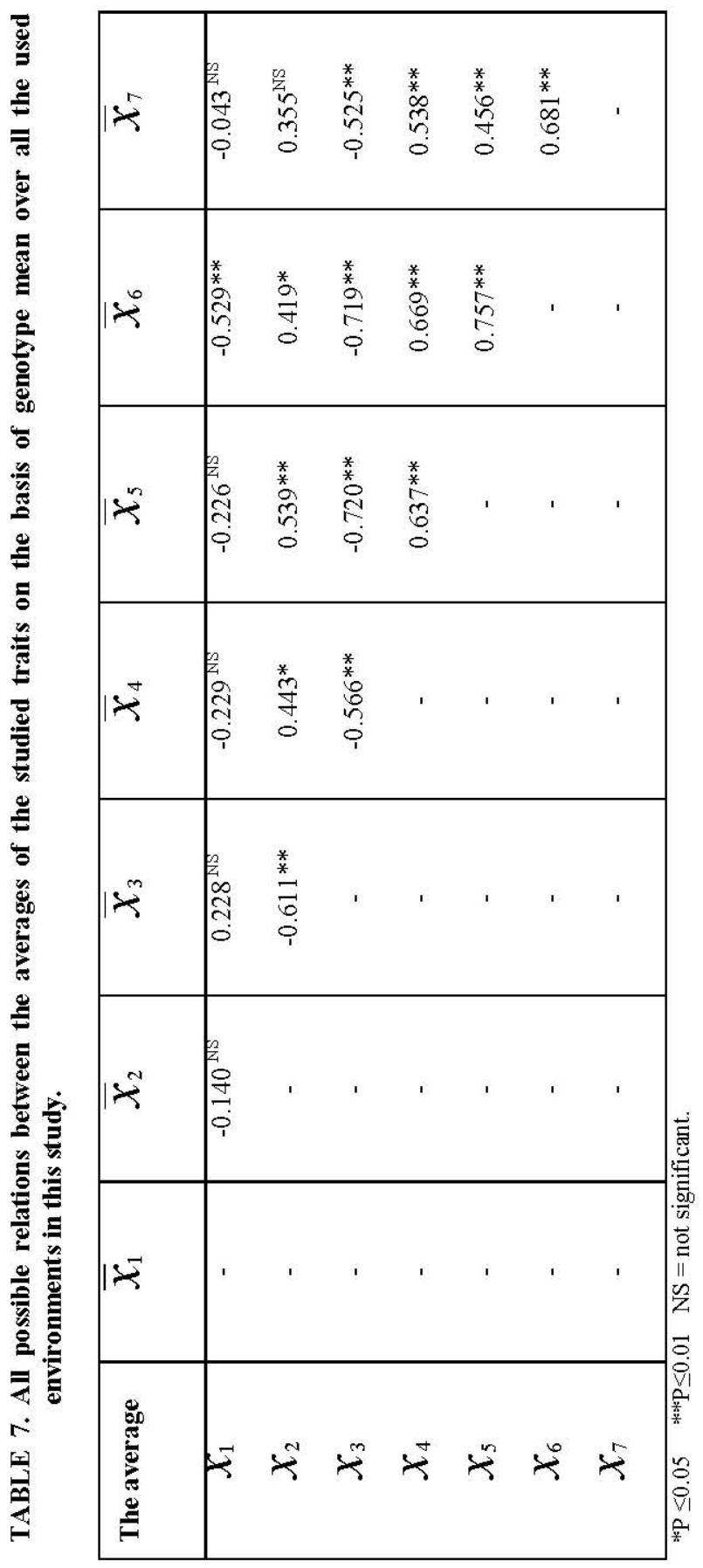

Egypt. J. Agron. 36, No. 2 (2014) 
For instance, the relationship between yield and each of its other six studied components [days to heading $\left(\overline{\boldsymbol{x}}_{1}\right)$, No of spikes plant" $\left(\overline{\boldsymbol{x}}_{2}\right)$, No. of kernels/spike $\left(\overline{\boldsymbol{x}}_{3}\right)$, spike kernels weight $\left(\overline{\boldsymbol{x}}_{4}\right), 1000$ kernels weight $\left(\overline{\boldsymbol{X}}_{5}\right)$ and harvest index $\left(\overline{\boldsymbol{x}}_{7}\right)$ ] in this work were $-0.53^{* *}, 0.41^{*},-0.72^{* *}, 0.67 * *, 0.76^{* *}$ and $0.68^{* *}$, respectively (Table 7 ).

These results indicate that wheat breeders should select the earlier plants which have improved number of spikes, spike kernels weight and, in particular, heavier 1000 kernels weight to improve grain yield using both production index $(\overline{\boldsymbol{x}})$ and the estimated stability parameters in this work. Where, Bansal \& Sinha (1991b) stated that the stability in grain yield of T. aestivum (Landraces and improved wheat cultivars) under stress conditions was strongly depended on the stability in spikes either per unit area or per plant. In addition, our results were in agreement with those obtained by EI-Morshidy et al. (1998 and 2000) and Yan \& Hunt (2001).

Moreover, our data emphasize that both mean performance of a genotype and its stability parameters should be taken together into consideration to recommend such new genotype to be used in varying environments. Whereas, previous studies illustrated that the promising genotypes were Ahgaf, Giza 163 and Giza 160 , these genotypes which all showed to have at most higher average of performance than the grand mean and also acceptable stability parameters to its studied traits (EI-Morshidy et al., 1998 and 2000). Although selection based upon yield per se should be the most efficient method for increasing the mean yield of a population (Wells \& Kofoid, 1986). Parveen et al. (2010) noticed some cultivars as stable on the basis of overall mean yields and stability parameters viz., regression coefficients and minimum deviations from regression.

Thus, according to Eberhart \&Russell (1966), the genotypes no. 13, 14 and 22 may be considered superior under abiotic stresses (heat and drought) because they showed high mean performance when compared with grand mean beside acceptable stability parameters to the studied traits under these conditions as follows:

\begin{tabular}{|c|c|c|c|c|c|c|c|c|}
\hline \multirow[b]{2}{*}{$\begin{array}{c}\text { No. of } \\
\text { genotype }\end{array}$} & \multirow[b]{2}{*}{ Item } & \multicolumn{7}{|c|}{ Characters } \\
\hline & & $\begin{array}{l}\text { Days to } \\
\text { heading }\end{array}$ & $\begin{array}{c}\text { No. of } \\
\text { spikes/ } \\
\mathbf{m}^{2}\end{array}$ & $\begin{array}{c}\begin{array}{c}\text { No. of } \\
\text { kernels/ }\end{array} \\
\text { spike }\end{array}$ & $\begin{array}{c}\text { Spike } \\
\text { kernels } \\
\text { weight }\end{array}$ & $\begin{array}{c}1000 \\
\text { kernel } \\
\text { weight }\end{array}$ & $\begin{array}{c}\text { Grain } \\
\text { yield } / \mathbf{m}^{2}\end{array}$ & $\begin{array}{c}\text { Harvest } \\
\text { index }\end{array}$ \\
\hline $\begin{array}{c}13 \\
\text { (NGB10893) } \\
\end{array}$ & $\begin{array}{c}\text { Mean } \\
\text { Stability }\end{array}$ & $\begin{array}{c}\text { Equal to } \\
\text { stable }\end{array}$ & $\begin{array}{l}\text { Higher } \\
\text { stable }\end{array}$ & $\begin{array}{c}\text { Medium } \\
\text { stable }\end{array}$ & $\begin{array}{c}\text { Higher } \\
\text { unstable }\end{array}$ & $\begin{array}{l}\text { Higher } \\
\text { stable }\end{array}$ & $\begin{array}{l}\text { Higher } \\
\text { stable }\end{array}$ & $\begin{array}{c}\text { Medium } \\
\text { stable }\end{array}$ \\
\hline $\begin{array}{c}14 \\
\text { (Sids 1) }\end{array}$ & $\begin{array}{c}\text { Mean } \\
\text { Stability }\end{array}$ & $\begin{array}{c}\text { Late } \\
\text { unstable }\end{array}$ & $\begin{array}{l}\text { Higher } \\
\text { stable }\end{array}$ & $\begin{array}{l}\text { Higher } \\
\text { stable }\end{array}$ & $\begin{array}{l}\text { Higher } \\
\text { stable }\end{array}$ & $\begin{array}{l}\text { Higher } \\
\text { stable }\end{array}$ & $\begin{array}{l}\text { Higher } \\
\text { stable }\end{array}$ & $\begin{array}{c}\text { Higher } \\
\text { stable }\end{array}$ \\
\hline $\begin{array}{c}22 \\
\text { (Giza 168) }\end{array}$ & $\begin{array}{c}\text { Mean } \\
\text { Stability }\end{array}$ & $\begin{array}{l}\text { Early } \\
\text { stable }\end{array}$ & $\begin{array}{c}\text { Lower } \\
\text { unstable }\end{array}$ & $\begin{array}{l}\text { Higher } \\
\text { stable }\end{array}$ & $\begin{array}{l}\text { Higher } \\
\text { stable }\end{array}$ & $\begin{array}{l}\text { Higher } \\
\text { stable }\end{array}$ & $\begin{array}{l}\text { Higher } \\
\text { stable }\end{array}$ & $\begin{array}{c}\text { Higher } \\
\text { stable }\end{array}$ \\
\hline
\end{tabular}

Egypt. J. Agron. 36, No. 2 (2014) 
In reality, the genotypes no. 13 (NGB10893), 14 (Sids 1) and 22 (Giza 168) are recommended and adapted to use in abiotic stresses (heat and drought) environments. The breeder should compromise the relationship between an average of performance of a genotype and its stability parameters.. Thus, the breeders are often requested to recommend the highest yielding genotypes irrespective of whether a genotype is stable over all traits or no.

\section{References}

Abd-Elghani, A.M., Abd-EI Shafi, A.M. and EI-Monofi, M.M. (1994) Performance of some wheat germplasm adapted to terminal heat stress in Upper Egypt. Assiut J. Agric. Sci. 25, 59-67.

Abdullah, M., Rehman, A., Ahmad, N. and Rasul, I. (2007) Planting time effect on grain and quality characteristics of wheat. Pak. J. Agri. Sci. 44, 200-202.

Akçura, M., Kaya, Y. and Taner, S. (2005) Genotype-environment interaction and phenotypic stability analysis for grain yield of durum wheat in the Central Anatolian Region. Turk. J Agric. 29, 369 - 375.

Anwar, J., Ahmad, A., Khaliq, T., Mubeen, M. and Sultana, S.R. (2011) Optimization of sowing time for promising wheat genotypes in semiarid environment of Faisalabad. Crop \& Environment, 2(1), 24-27.

Bansal, K.C. and Sinha, S.K. (1991 b) Assessment of drought resistance in 20 accessions of Triticum aestivum L. and related species. 11- Stability in yield components. Euphytica, 56, 15-26.

Björnsson, I. (2002) Stability analysis towards understanding genotype x environment interaction. Plant Agriculture Department of University of Guelph,Ontario, Canada. www.genfys.slue.se/staff/deg/nova02.

Bose, L.K., Jambhulkar, N. N. , Pande, K. and Singh, O. N. (2014) Use of AMMI and other stability statistics in the simultaneous selection of rice genotypes for yield and stability under direct-seeded conditions. Chilean J. Agric. Res. 74 (1) Chillán mar., on-line ISSN 0718-5839.

Clarke, J.M. and Townley-Smith, T.F. (1984) Screening and selection techniques for improving drought resistance. In: "Crop Breeding". P.B. Vose and S.G. Blikt (Ed.) pp. 137-162. (Pergamon Press).

Eberhart, S.A. and Russell, W.A. (1966) Stability parameters for comparing varieties. Crop Sci. 6, 36-40.

EI-Defrawy, M.M., Kheiralla, K.A. and Dawood, R.A. (1994) Effect of genotypes, moisture stress and stability analysis on grain yield and some quality traits in wheat. Assiut J. Agric. Sci. 25, 341-360.

EI-Morshidy, M.A., Tammam, A.M., Abd EI-Gawad, Y.G. and Elorong, E.E.M. (1998) Mean performance of some wheat genotypes as influenced by some cultural practices under new valley conditions. Assiut J. Agric. Sci. 29, 1-22. 
EI-Morshidy, M.A., Elorong, E.E.M., Tammam, A.M. and Abd EI-Gawad, Y.G. (2000) Analysis of genotype $x$ environment interaction and assessment of stability parameters of grain yield and its components of some wheat genotypes (Triticum aestivum L.) under new valley conditions. The $2^{\text {nd }}$ Scientific Conf. of Agri. Sci., Oct., Assiut, 13-34.

Fisher, R.A. and Yates, F. (1953) Statistical Tables for Biological, Agricultural, and Medical Research." Olive and Boyd", Edinbugh, p.94.

Francis, T. R. and Kannenberg, L.W. (1978) Yield stability studies in short-season maize. 1. A descriptive method for grouping genotypes. Can. J. Plant Sci. 58, 10291034 .

Gomez, K.A. and Gomez, A.A. (1984) "Statistical Procedures for Agricultural Research". Wiley-Interscience Publ. John Wiley \& Sons Inc. New York, USA

Hamidou, F., Halilou, O. and Vadez, V. (2013) Assessment of groundnut under combined heat and drought stress. J. Agronomy and Crop Sci. 199(1), 1-11.

Ismail, A.A. (1995) The performance and stability of some wheat genotypes under different environments. Assiut J. Agric. Sci. 26, 15-37.

Joppa, L.R, Lebsock, K.L. and Bush, R.H. (1971) Yield stability of selected spring wheat cultivars (T. aestivum L.) in uniform regional nureries, Crop Sci. 11, 238-241.

Kheiralla, K.A. and Ismail, A.A. (1995) Stability analysis for grain yield and some traits related to drought resistance in spring wheat. Assiut J. Agric. Sci. 26, 253- 266.

Kheiralla, K.A., Mahdy, E.E. and Dawood, R.A. (1988) Evaluation and genotypic stability of some accessions of multi-cut Egyptian clover. Assiut. J. Agric Sci. 19 (4), 51-64.

Kheiralla, K.A., EI-Morshidy, M.A., Motawea, M.H. and Saeid, A.A. (2004) Performance and stability of some wheat genotypes under normal and water stress conditions. Assiut J. Agric. Sci. 35 (2), 74- 94.

Koumber, R.M., El-Hashash, E.F. and Seleem, S.A. (2011) stability analysis and genotype $\mathrm{x}$ environment interaction for grain yield in bread wheat. Bull. Fac.Agric., Cairo Univ. 62, 457-467.

Langer, I., Frey, K.J. and Bailey, T. (1979) Associations among productivity, production response and stability indexes in oat varieties. Euphytica, 28, 17-24.

Moldovan, V., Moldovan, M. and Kadar, R. (2000) Item from Romania. S.C.A. Agricultural Research Station. Turda, 3350, str. Agriculturii 27 Jud Chuj, Romania.

Mustãţea1, P., Saulescu, N.N., Ittu1, G., Paunescu, G.,Voinea, L., Stere, I., Mîrlogeanu, S., Constantinescu, E. and Nastase, D. (2009) Grain yield and yield stability of winter wheat cultivars in contrasting weather conditions. Romanian Agric. Res. 26, $1-8$.

Nachit, M.M. and Ouassou, A. (1988) Association of yield potential, drought tolerance and stability in Triticum turgidum var. durum. Seventh International Wheat Genet Symposium, (1), pp. 867-870.

Egypt. J. Agron. 36, No. 2 (2014) 
Nachit, M.M., Nachit, G., Ketata, H., Gauch, H.G. and Zobel, R.W. (1992) Use of AMMI and linear regression models to analyze genotype - environment Interaction in durum wheat. Theor. App. \& Genet. 83, 597-601

Ortiz-Ferrara, G., Yau, S.K. and Moussa, M.A. (1991) Identification of agronomic traits associated with yield under stress conditions. "Physiology-Breeding of Winter Cereals for Stressed Mediterranean Environments". (ICARDA) Ed. INRA Paris.

Parveen, L., Khalil, I.H. and Khalil, S.K. (2010) Stability parameters for tillers, grain weight and yield of wheat cultivars in north-west of Pakistan. Pak. J. Bot. 42(3), $1613-1617$.

Perkins, J.M. and Jinks, J.L. (1968) Environmental and genotype environmental components of variability. Ill. Multiple lines and corsses. Heredity, 23, 339-356.

Pinthus, M.J. (1973) Estimate of genotypic value a proposed method. Euphytica, 2, 121-123.

Rehman, H., Farooq, M. and Afzal, I. (2007) Late sowing of wheat by seed priming. http://www.pakissan.com/english/index.html.

Saini, D.P. and Gautum, P.L. (1990) Note on G x E analysis in segregation populations of durum wheat. Indian J. Genet. 50, 199-201.

Salem, A. H., Rabie, H.A. and Selim, M.S. (1990) Stability analysis for wheat grain yield. Egypt J. Appl. Sci. 5, 225-237.

Sharma, D.L., D'Antuono, M., Mohammad, A., Shackley, B.J., Zaicou-Kunesch, C.M. and Anderson, W. K. (2006) Differences among wheat cultivars in their optimum sowing times in Western Australian environments. Proceedings of $13^{\text {th }}$ Agronomy Conf., Sept., Perth, Western Australia.

Shindin, I.M. and Lokteva, O.V. (2000) Evaluation of spring wheat varieties at Primorskey for ecological plasticity. Ann. Wheat. Newslet. 46, 105- 106.

Sial, M.A., Dahot, M.U., Arain, M.A., Mangrio, S.M., Naqvi, M.H. and Nizamani, N.A. (2005) Effect of time of planting and heat stresses on wheat advanced genotypes. Pakistan Journal of Biotechnology, 2(1-2), 13-23.

Wajid, A., Hussain, A., Ahmad, A., Goheer, A.R., Ibrahim, M. and Mussaddique, M. (2004) Effect of sowing date and plant population on biomass, grain yield and yield components of wheat. Int. J. Agri. Bio. 6, 1003-1005.

Wells, W.C. and Kofoid, K.D. (1986) Selection indices to improve an intermating population of spring wheat. Crop Sci. 26, 1104-1109.

Yan, W. and Hunt. L.A. (2001) Interpretation of genotype by environment interaction for winter wheat yield in Ontario. Crop Sci. 41, 19-25.

(Received 20/7/2014;

accepted 19/10/2014) 


\section{مقاييس الثبات لمقارنة بعض التراكيب الوراثية لقمح الخبز تحت ظروف الجفاف والحرارة

\author{
نحيف ابراهيم محمد و علاء علي سعيد

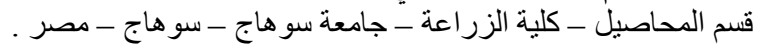

اجري هذا البحث لمقارنة ب ب تركيب وراثي محلي ومستورد لتحمل الحرارة

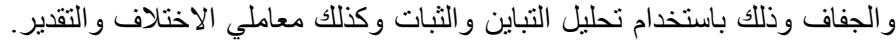

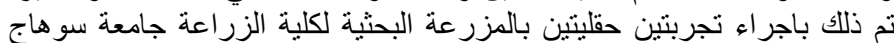

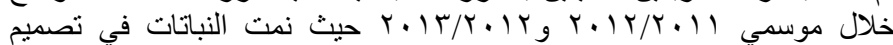

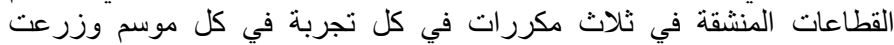

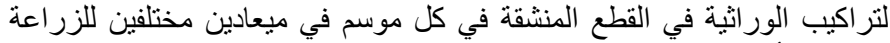

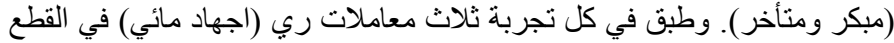

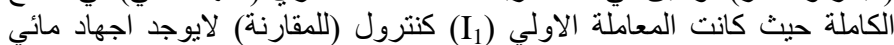

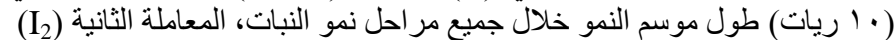

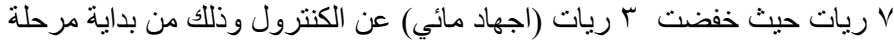

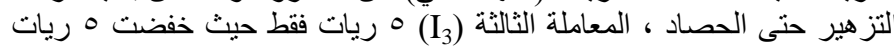

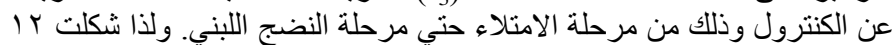

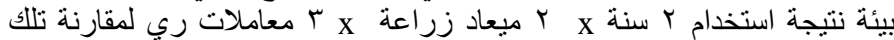

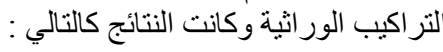

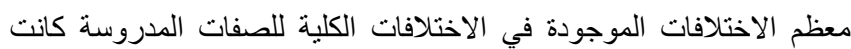

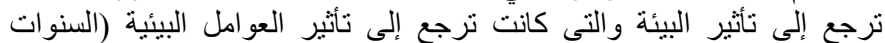

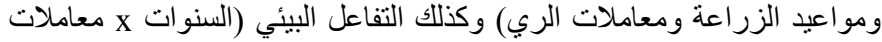

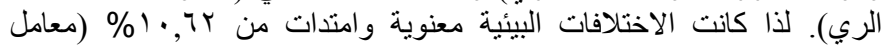

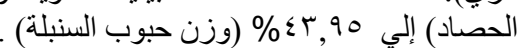

كانت هنالك فروق احصائية بين التر اكيب الور اثية في جميع الصفات المدروسة الصات

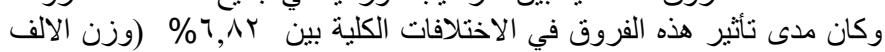

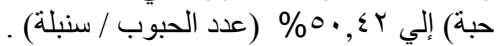

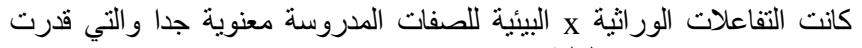

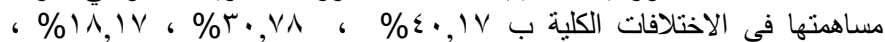

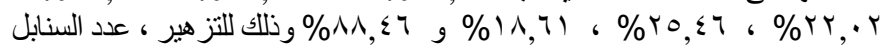

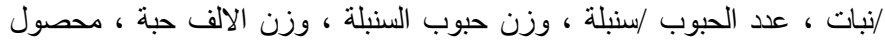

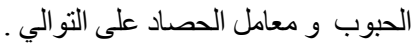

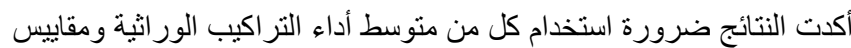

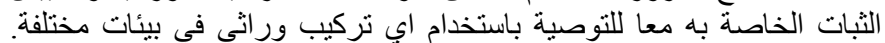

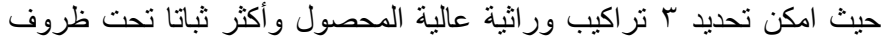

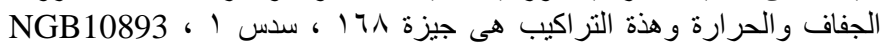

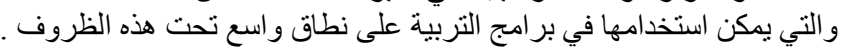

